Supplement of

\title{
Chemical and climatic drivers of radiative forcing due to changes in stratospheric and tropospheric ozone over the 21st century
}

Antara Banerjee et al.

Correspondence to: Antara Banerjee (ab4283@ columbia.edu)

The copyright of individual parts of the supplement might differ from the CC BY 4.0 License. 


\begin{tabular}{|c|c|c|c|}
\hline & $\Delta\left[\mathrm{CH}_{4}\right]_{\mathrm{ss}}{ }^{1}[\mathrm{ppmv}]$ & $\mathrm{RF}-\mathrm{CH} 4_{\mathrm{ss}}{ }^{2}\left[\mathrm{~W} \mathrm{~m}{ }^{-2}\right]$ & $\mathrm{RF}-\mathrm{O} 3_{\mathrm{ss}}{ }^{3}\left[\mathrm{~W} \mathrm{~m}{ }^{-2}\right]$ \\
\hline$\Delta \mathrm{CC} 4.5$ & -0.25 & -0.10 & $\begin{array}{c}0.07 \\
(-0.02)\end{array}$ \\
\hline$\Delta \mathrm{CC} 8.5$ & -0.54 & -0.22 & $\begin{array}{c}0.02 \\
(-0.05)\end{array}$ \\
\hline$\Delta \mathrm{ODS}$ & 0.09 & 0.03 & $\begin{array}{c}0.07 \\
(0.01)\end{array}$ \\
\hline$\Delta \mathrm{O} 3$ pre & 0.08 & 0.03 & $\begin{array}{l}-0.09 \\
(0.01)\end{array}$ \\
\hline
\end{tabular}

Table S1. Estimates of changes in the global abundance of tropospheric $\mathrm{CH}_{4}\left(\Delta\left[\mathrm{CH}_{4}\right]_{\mathrm{ss}}\right)$ from its imposed concentration of 1.75 ppmv to steady state after accounting for adjustments through changes in the $\mathrm{CH}_{4}$ lifetime. Also reported (to 2 decimal places) are the associated tropospheric $\mathrm{RF}$ due to $\mathrm{CH}_{4}\left(\mathrm{RF}-\mathrm{CH} 4_{\mathrm{ss}}\right)$ and ozone $\left(\mathrm{RF}-\mathrm{O3}_{\mathrm{ss}}\right)$.

${ }^{1} \Delta\left[\mathrm{CH}_{4}\right]_{\mathrm{ss}}[\mathrm{ppmv}]$ has been estimated following the methodology detailed in Banerjee et al. (2014, 2016) (and references therein) using the model-specific feedback factor of 1.52 .

${ }^{2} \mathrm{RF}-\mathrm{CH} 4_{\mathrm{ss}}\left[\mathrm{Wm}^{-2}\right]$ corresponds to the direct $\mathrm{RF}$ of $\mathrm{CH}_{4}$ that would result from $\Delta\left[\mathrm{CH}_{4}\right]_{\mathrm{ss}}$ relative to a baseline concentration of 1.75 ppmv, and is calculated using the simple expression in Myhre et al. (1998) (using $\left[\mathbf{N}_{2} \mathrm{O}\right]=327 \mathrm{ppbv}$ ).

${ }^{3} \mathrm{RF}-\mathrm{O3}_{\mathrm{ss}}\left[\mathrm{Wm}^{-2}\right]$ is the estimate of the tropospheric ozone $\mathrm{RF}$ that would result at steady state (bracketed values indicate the difference from Table 2 in the main text where $\mathrm{CH}_{4}$ feedbacks are neglected). This is obtained by first scaling $\Delta\left[\mathrm{CH}_{4}\right]_{\mathrm{ss}}$ as in Banerjee et al. $(2014,2016)$ on a gridbox and monthly mean basis to obtain the corresponding change in ozone abundance. A steady state ozone field $\left(\left[\mathrm{O}_{3}\right]_{\mathrm{ss}}\right)$ is calculated as the sum of this change and the simulated ozone. $\mathrm{RF}-\mathrm{O} 3_{\mathrm{ss}}$ is then calculated by applying $\left[\mathrm{O}_{3}\right]_{\mathrm{ss}}$ as a perturbation within the offline RTM. 